\title{
Southern Africa: The Missing Piece To The Dust Provenance Puzzle of East Antarctica?
}

\section{Stefania Gili ( $\nabla$ sgili@princeton.edu )}

Princeton University https://orcid.org/0000-0001-9506-9016

Aubry Vanderstraeten

Princeton University

Amélie Chaput

Université de Montréal

James King

Université de Montréal

Diego Gaiero

Universidad Nacional de Córdoba

Barbara Delmonte

University of Milano-Bicocca

Paul Vallelonga

University of Western Australia

Paola Formenti

Université de Paris and Univ Paris Est Creteil

Claudia Di Biagio

Université de Paris and Univ Paris Est Creteil

Mathieu Cazanau

Université de Paris and Univ Paris Est Creteil

Edouard Pangui

Université de Paris and Univ Paris Est Creteil

Jean-François Doussin

Univ Paris Est Creteil and Université de Paris

Nadine Mattielli

Université Libre de Bruxelles (ULB)

\section{Article}

Keywords: SAF, AUS, Dust Provenance, Antarctica

Posted Date: September 29th, 2021 
DOl: https://doi.org/10.21203/rs.3.rs-923449/v1

License: (c) (1) This work is licensed under a Creative Commons Attribution 4.0 International License. Read Full License

Version of Record: A version of this preprint was published at Communications Earth \&amp; Environment on June 9th, 2022. See the published version at https://doi.org/10.1038/s43247-022-00464-z. 


\section{Southern Africa: The Missing Piece to the Dust Provenance Puzzle of East Antarctica?}

2

Stefania Gilii ${ }^{\mathrm{a}, \mathrm{b} *}$, Aubry Vanderstraeten ${ }^{\mathrm{a}, \mathrm{c}}$, Amélie Chaput ${ }^{\mathrm{d}}$, James King ${ }^{\mathrm{d}}$, Diego M. Gaiero ${ }^{\mathrm{e}}$, Barbara Delmonte $^{\mathrm{f}}$, Paul Vallelonga ${ }^{\mathrm{g}}$, Paola Formenti ${ }^{\mathrm{h}}$, Claudia Di Biagio ${ }^{\mathrm{h}}$, Mathieu Cazanau $^{\text {h}}$, Edouard Pangui ${ }^{\mathrm{h}}$, Jean-François Doussin ${ }^{\mathrm{i}}$ and Nadine Mattielli ${ }^{\mathrm{a}}$

aLaboratoire G-Time, Département Géosciences, Environnement et Société (DGES), Université Libre de Bruxelles (ULB), Brussels, Belgium.

${ }^{\mathrm{b}}$ Department of Geosciences, Princeton University, Princeton, New Jersey, USA.

c Univ. Littoral Côte d'Opale, CNRS, Univ. Lille, UMR 8187 - LOG - Laboratoire d'Océanologie et de Géosciences, F-62930 Wimereux, France.

${ }^{\text {d }}$ Laboratoire d'Érosion Éolienne, Département de Géographie, Université de Montréal, Montréal, Canada.

${ }^{\mathrm{e}}$ CICTERRA/CONICET, Universidad Nacional de Córdoba, Córdoba, Argentina.

${ }^{\mathrm{f}}$ Department of Environmental and Earth Sciences, University of Milano-Bicocca, Italy. g UWA Oceans Institute, University of Western Australia, Perth, Australia.

${ }^{\mathrm{h}}$ Université de Paris and Univ Paris Est Creteil, CNRS, LISA, F-75013 Paris, France.

${ }^{\mathrm{i}}$ Univ Paris Est Creteil and Université de Paris, CNRS, LISA, F-94010 Créteil, France.

*Corresponding author: Stefania Gili (sgili@princeton.edu)

\section{Abstract}

Mineral dust is a natural tracer of atmospheric composition and climate variability. Yet, there is still much to be known about the Southern Hemisphere dust cycle during the last Pleistocene. Major efforts have attempted to solve the 'puzzle' of the origin of the potential source areas that contribute dust to the Southern Ocean and East Antarctica. Here we present a comprehensive geochemical characterization of an important potential source area, which role as a dust supplier to different environments of the SH has significantly been underestimated, that is, the Southern Africa (SAF) region. On the basis of $\mathrm{Sr}-\mathrm{Nd}-\mathrm{Pb}$ isotope ratios and rare earth element concentrations analyzed in sediments collected along the major dust-producing areas in the Namibian coast (Kuiseb, Omaruru and Huab riverbeds and the Namibian sand sea region), this study demonstrates for the first time that SAF emerges as the second most important dust source to EA during interglacial times. 


\section{Introduction}

Mineral dust is considered a sensitive natural tracer of modern and past environmental conditions and a paleoclimatic proxy that reflects the variations in the atmospheric circulation during different climatic periods and their transitions. The type and intensity of dust emissions are a consequence of different conditions at the source (sediment supply and availability) and aeolian processes (deflation, transport, deposition)(e.g., Shao et al., 2010). Once dust is emitted into the atmosphere, it remains in suspension until physical and chemical conditions favor its deposition. The deposited dust is archived in different proxy records either, over the oceans or onto continental land-masses within ice cores, deep sea sediments, loess, peat bogs, etc. For the Southern Hemisphere, reconstructions of dust buried in Antarctic ice cores are considered an excellent proxy for the paleo-record of wind patterns and its intensity. In this regard, these records indicated that dust fluxes were up to $\sim 25$ times higher during glacial periods due to dust production strengthening at their source areas, compared to warmer periods when dust concentrations were extremely low (Lambert et al., 2008).

Introduced by Delmonte et al. (2004a), the term Potential Source Areas (PSAs) denotes either a primary source of mineral dust, derived directly from the physical and/or the chemical weathering of the parent material or a secondary source for dust, where aerosol particles have already been subjected to a phase of aeolian and/or fluvial transport. For the Southern Hemisphere, Southern South America (SSA), Australia (AUS), New Zealand (NZ), Southern Africa (SAF), and the Antarctic Dry Valleys have all been identified as PSAs. The first study to trace the dust origin in Antarctica ice cores was Grousset et al. (1992). In agreement with the $\mathrm{Sr}-\mathrm{Nd}$ isotope data presented in that study, all the studies since have demonstrated that the main dust contributor to the Southern Ocean (SO) and East Antarctica (EA) during glacial (MIS2-MIS20) and interglacial periods is SSA, mainly from Patagonia (e.g., Basile et al., 1997; Delmonte et al., 2004a; 2019; Gaiero, 2007; Gili et al., 2016, 2017; Vallelonga et al., 2010). Despite the agreement on the dominance of a Patagonian dust origin during glacial periods there is presently a debate regarding the Holocene dust PSAs with the following scenarios of dust provenance proposed: $i$ ) a weakened Patagonian source complemented by a lower latitude source region (Southern Central West Argentina, SCWA) (Gaiero, 2007; Gaiero et al., 2004; Gili et al., 2017); ii) a Puna-Altiplano dust source transported via the southern tropical jet stream (Gaiero, 2007; Gaiero et al., 2013; Gili et al., 2016, 2017) and, iii) a general contribution from Southern South America plus a secondary input from AUS (De Deckker et al., 2010; Du et al., 2018; Revel-Rolland et al., 2006) or NZ (Wegner et al., 2012). Some of these interpretations were partially supported by Atmospheric General Circulation Models (AGCM), 
suggesting that while SSA dust dominates deposition over the Atlantic Southern Ocean and East Antarctica, AUS modern dust prevails over the Pacific SO and towards the western coastal regions of Antarctica (Albani et al., 2012; Li et al., 2008). Neff and Bertler (2015) concluded from back-trajectory modeling that the transportation of aeolian material from NZ to the southern high latitudes is possible. On the contrary, a recent study carried out in sediments from the major present-day dust and sediment producing regions of the South Island in NZ, has indicated this area was not a significant dust supplier to EA (Koffman et al., 2021). Using AGCMs, Li et al. (2008) showed that after SSA and AUS, Southern Africa is the third main dust supplier in the Southern Hemisphere with dust depositions mainly taking place in the South Atlantic and Indian Ocean. Even though this region is a significant dust emission source, little is still known about it being a PSA as the geochemical and modeling data available for this region is extremely sparse. Thus, it is questionable if the role of SAF as a dust contributor to the SO and EA has plausibly been underestimated. For many years, only the Makgadikgadi Pan in Botswana and the Etosha Pan in Namibia were recognized as persistent dust sources in SAF (e.g., Prospero et al., 2002; Bryan et al., 2003; Mahowald et al., 2003; Li et al., 2008), neglecting the coastal Namibian sources. In fact, it was only until recently that the Namib Desert coast has been identified as one of the largest sources of dust in Southern Africa (Von Holdt et al., 2017; Vickery et al., 2013). Using remote sensing satellite images, these authors have found that along the southwestern coast of SAF, the Kuiseb, Omaruru, and Huab Rivers beds are the three main areas of greatest dust emission located on recently deposited fluvial surfaces. Revisiting the literature, it became apparent that while most of the studies have been focused on the detailed study of SSA, AUS and most recently NZ dust sources (e.g., Gili et al., 2017; DeDeckker et al., 2019, Koffman et al., 2021), other PSAs, such as SAF, have been overlooked. Thus, there arises a compelling need for more extended geochemical studies to fill the current gap in understanding the past and present long-range transportation of mineral dust particles to the high-latitude environments.

Responding to this need, this study aims to investigate the role of SAF as a PSA and provides the first comprehensive north-to-south geochemical characterization of riverbed sediments collected along the major dust producing river systems in the Namib desert (Huab, Omaruru and Kuiseb). Combining rare earth elements (REE) concentrations and the $\mathrm{Sr}-\mathrm{Nd}-\mathrm{Pb}$ isotope compositions, we seek to evaluate the influence of this region as a dust source to the high latitude environments of the Southern Hemisphere. We compare the geochemical signature of bulk and resuspended aerosol fractions from SAF, with the dust fingerprint reported for Antarctic ice cores (Vostok and EDC) during glacial (MIS2-MIS20) and interglacial periods 
(Holocene and MIS 5.5). In addition, we also include a re-analysis of the isotopic composition of SAF samples previously reported in Delmonte et al. (2004a) and Vallelonga et al. (2010).

\section{Geological and Climatic Settings}

Namibia is located at the intersection of the Mesoproterozoic Namaqua and Neoproterozoic Damara orogenic belts welding the Archean Kalahari and Congo Cratons (Fig. 1a; Jacobs et al., 2008). The Namib desert extends N-S for approximately $2000 \mathrm{~km}$ along the western coast of southern Africa between the Kunene and Orange Rivers (Fig. 1a; Heine and Heine, 2002).

The geology of the region is dominated by the lithological sequence of the Damara Orogenic system including 2.0-1.2 Ga gneissic basement overlaid by Neoproterozoic to Paleozoic metasediments intruded by $840-460$ Ma granitic. Granites are the most common igneous rock type (c. 94\%), while the remaining intrusions are equally subdivided between diorite and tonalite/granodiorite (Miller, 1983; 2008). The eastern border for the Namib desert is delimited by the Great Escarpment ( 2000 m high) running parallel to the coast and 100-150 km inland (Fig. 1a). Along the Between the Kunene and the Orange Rivers, twelve aligned ephemeral river valleys extend sub-parallel east-west along the Atlantic Coast (Jacobson et al., 1995). Sporadic summer rainfalls of $<25 \mathrm{~mm} \mathrm{yr}^{-1}$ in coastal areas (Eckardt et al., 2013) sometimes generate floods of several days but otherwise, these river beds stay dry. The limited rainfall water dissipates due to infiltration and evaporation, while any fluvial transported sediments are deposited along river valley channels making them available for aeolian entrainment and transport.

In this study, sediments from three of the driest river valleys along the coast, the Huab, Omaruru, and Kuiseb are investigated (Fig.1a). These valleys cross the Damara Belt, where the main catchments are dominated by fluvial sands from the Damara Orogenic belt (Jacobsen et al., 1995). The Huab River sand composition is mainly composed of feldspars and quartz (Garzanti et al., 2014). Omaruru and Kuiseb mainly draw sediments from the Damara branch, which widely exposes highly metamorphosed rocks and granitoid intrusions (Garzanti et al., 2014; Jung and Mezger, 2003). The Kuiseb valley also runs along the northern edge of the Namib sand sea (Fig.1a), where the Orange River sediments, which are shown to be pushed northward by the dominant southerly winds and powerful along-shore currents, are known to be the predominant bed-load sediment source (Vermeesch et al., 2010; Jacobson et al., 1995; Lancaster, 1983) despite being $1500 \mathrm{~km}$ apart (e.g., Compton et al., 2010).

The regional atmospheric circulation patterns and the arid climate of the Namibian coast are produced by a quasi-stationary subtropical South Atlantic anticyclone and the cold northward- 
flowing Benguela current (Compton et al., 2004). For most of the year, strong onshore southto-southwesterly trade winds over the dry river valley regions are responsible for $90 \%$ of the sand flux, especially during winter and spring (Tlhalerwa et al., 2005; Todd and Washington, 1999)(Fig.1b). Northeasterly 'Bergwinds' are also another important agent of aerosol transportation and deposition off the west coast of SAF because of their high velocities and subsidence offshore (Fig.1b). Common from April to August, Bergwinds are shown to be responsible for $>60 \%$ of the offshore sediment transport with dust plumes extending $\geq 100 \mathrm{~km}$ into the Southern Ocean (Vickery et al., 2013). In addition, with an estimated annual dust input of 4.4 tones into the South Atlantic Ocean, this wind system is in charge of supplying nutrients to the highly fertile Benguela upwelling (Tlhalerwa et al., 2005). Namibia's offshore waters are dominated by the Benguela upwelling system, which is wind-driven by the regional alongshore southeast trade winds and recognized for being a region with the highest rates of primary production in the ocean where dust with high nutrient content deflated from the continent, it is discharged offshore fertilizing the ocean waters (Jickells et al., 214). Although minimum annual variations in wind intensities occur, the Benguela upwelling system is often separated into three zones; north, central, and south (Jury, 2012). The north and south Benguela upwelling zones are respectively bounded by the Angola and Agulhas Currents. The central zone presents the least fluctuating regime and is the most relevant zone for our research as it lies contiguous to the main dust source region investigated here between $22^{\circ}$ and $28^{\circ} \mathrm{S}$.

\section{Sampling and analytical methods}

With the aim to evaluate the provenance and the long-range transportation of dust depositions in remote areas potentially related to Southern Africa PSAs, surface sediment samples were collected across the lower valleys of Huab, Omaruru, and Kuiseb rivers (Fig. 1a, red dots. See table S1 for more details). A total of 22 bulk samples ( 9 samples from Huab, 7 from Omaruru and 6 from Kuiseb) were analyzed in terms of their REE concentrations and $\mathrm{Sr}-\mathrm{Nd}-\mathrm{Pb}$ isotope compositions. Additionally, measurements of $\mathrm{Sr}-\mathrm{Nd}-\mathrm{Pb}$ isotope ratios were carried out in 5 bulk and 5 fine $(<5 \mu \mathrm{m})$ fraction samples from the Namib Sand Sea (Fig. 1a, blue diamonds), to produce a comparable result to the bulk samples previously analyzed by Delmonte et al. (2004) and Vallelonga et al. (2010). Furthermore, to assess a possible change in the geochemical fingerprint due to grain-size effects, six bulk samples from the Huab valley were selected to generate airborne aerosols dust in the fine fraction $(\sim<11 \mu \mathrm{m})$ using an atmospheric simulation chamber (see section 3.1 and supplementary materials for further details). The 
aerosol fraction investigated in this study has also important implications for provenance studies as only certain particle sizes can be transported long distances. Hence, analyzing the right size fraction in the source region is crucial for to identify the origin of dust reaching the Southern Ocean and Antarctica.

\subsection{Sample collection}

Bulk surface samples from Huab, Omaruru and Kuiseb riverbeds were collected in a field camping in August 2017, using a trowel to obtain approximately $200 \mathrm{~g}$ of sediment from the surface. Sub-samples of $\sim 350 \mathrm{mg}$ were stored in pre-cleaned centrifuges tubes and shipped to Université Libre de Bruxelles (ULB), Belgium for analysis. From the bulk of six samples from Huab, dust aerosols (fine fraction) were generated into the CESAM atmospheric simulation chamber, to mechanically reproduce the saltation and sandblasting processes responsible for the release of mineral dust in natural conditions (Di Biagio et al., 2017). Briefly, dust aerosols are generated from the bulk sediments by a mechanical shaker and the aerosols are injected into the CESAM chamber, a stainless-steel reactor with a volume of $4.2 \mathrm{~m}^{3}$ (Wang et al., 2011) where dust is dispersed, left in suspension for $\sim 3$ hours, and ultimately recovered on acidcleaned $0.2 \mu \mathrm{m}$ Teflon filters. Additional details about the dust generation in the CESAM are provided in the supplementary material. The fine fraction $(<5 \mu \mathrm{m})$ of the Namibia Sand Sea samples was separated following the procedure explained in Delmonte et al. (2004a) using the Stoke's Law.

\subsection{Geochemical analyses}

Sample preparation and analyses for REE elemental and, $\mathrm{Sr}-\mathrm{Nd}-\mathrm{Pb}$ isotope compositions were carried out on bulk and fine fraction samples. Sediment samples were dissolved in an $\mathrm{HF}+\mathrm{HNO}_{3}$ mixture followed by an $\mathrm{HCl}$ bath in Savillex vials and $\mathrm{Sr}-\mathrm{Nd}-\mathrm{Pb}$ were separated through chromatography using ion-exchange resins following the procedure reported in Vanderstraeten et al. (2020). Isotopes were measured at the G-Time Lab, Universite Libre de Bruxelles (Belgium) using a High-Resolution ICP-MS Plasma $\mathrm{Nu}$ II ( $\mathrm{Nu}$ Instruments) in dry mode. The REE compositions were determined using a Quadrupole ICP-MS Agilent 7700. Additional details of the analytical methodology are provided in the supplementary material.

\section{Results}

\subsection{Southern Africa sediments and their Parental Rock Sources}


205 The REE concentrations and $\mathrm{Sr}-\mathrm{Nd}-\mathrm{Pb}$ isotopic compositions of the bulk and fine fraction of

206

207

208

209

210

211

212

213

214

215

216

217

218

219

220

221

222

223

224

225

226

227

228

229

230

231

232

233

234

235

236

237 sediments from the Huab, Omaruru, Kuiseb and Namibia Sea Sand are listed in Table S1.

The Southern Africa PSAs signature of the windblown samples presented in this study reflect the compositional variability of the locally outcropping rocks and sediments: a chemical and isotopic fingerprint that is the result of the mixing between the metasedimentary rocks from the Damara and the Kaoko belt and the Orange River (Garzanti et al., 2014; Goscombe et al., 2003) (Fig. S1).

\subsection{Rare Earth Elements (REE) Composition}

In Fig. 2, the composition of REE for the Southern Africa PSAs normalized to the upper crust (UCC, Taylor and McLennan, 1985) is plotted. This figure indicates that no significant difference in the REE composition prevails among all four areas characterized in this study and a regional differentiation is difficult. In general, samples show flat REE patterns with a minor decrease in the heavy REE abundances (Fig. 2a). Both the bulk and the fine fraction from Huab and Kuiseb exhibit $\mathrm{Eu} / \mathrm{Eu}^{*}<1$, with Omaruru displaying slightly higher values (Fig. 2b). The $\mathrm{Eu}$ anomaly $\left(\mathrm{Eu} / \mathrm{Eu}^{*}\right)$ was calculated with the equation $\mathrm{Eu} / \mathrm{Eu}^{*} 1 / 4$ $[\mathrm{Eu}] /(([\mathrm{Sm}]+[\mathrm{Gd}]) / 2)$. Figure $2 \mathrm{~b}$ also shows that the REE composition of the bulk and the fine fraction from the Huab area are very similar, suggesting bulk samples are representative of the fine particles and that Southern Africa REE signature is independent of the grain-size fraction of sediments. For comparison purposes, soil samples from the Walvis bay in Namibia have also been included, whose source has been attributed to the local dust blown from the nearby Namibia Sea Sand (Bayon et al., 2005).

\subsection{Strontium, Neodymium and Lead Isotopic Compositions}

Compared to REE data, the Huab, Omaruru, Kuiseb and Namib Sea Sand samples can be better discriminated based on their isotopic compositions (Fig. 3). Lead isotope compositions span within a relatively large range of values: ${ }^{206} \mathrm{~Pb} /{ }^{207} \mathrm{~Pb}: 1.15-1.28,{ }^{208} \mathrm{~Pb} /{ }^{207} \mathrm{~Pb}: 2.43-2.62$ defining variable $\mathrm{Pb}$ isotope fields (Fig. 3a). The Huab valley samples display intermediate values $\left({ }^{206} \mathrm{~Pb} /{ }^{207} \mathrm{~Pb}: 1.205-1.228,{ }^{208} \mathrm{~Pb} /{ }^{207} \mathrm{~Pb}: 2.482-2.518\right)$ between the Kuiseb and the Namibia Sea Sand regions which represent the highest and lowest (respectively) end-members in terms of $\mathrm{Pb}$ isotopic compositions. In this sense, the Kuiseb related samples have a more Thrich signature $\left({ }^{206} \mathrm{~Pb} /{ }^{207} \mathrm{~Pb}\right.$ : $\left.1.23-1.277,{ }^{208} \mathrm{~Pb} /{ }^{207} \mathrm{~Pb}: 2.495-2.612\right)$ indicating derivation from sources with higher $\mathrm{Th} / \mathrm{U}$ ratios. Contrarily, the Namib Sand Sea area shows comparatively the 
most unradiogenic $\mathrm{Pb}$ isotopic values $\left({ }^{206} \mathrm{~Pb} /{ }^{207} \mathrm{~Pb}: 1.159-1.206,{ }^{208} \mathrm{~Pb} /{ }^{207} \mathrm{~Pb}: 2.425-2.468\right)$, with a clear distinction between the bulk and the fine fractions. Interestingly, samples associated with the Omaruru valley define two isotopic subfields: one overlapping with Huab and a second field with less-radiogenic isotopic ratios $\left({ }^{206} \mathrm{~Pb} /{ }^{207} \mathrm{~Pb}: 1.181-1.212,{ }^{208} \mathrm{~Pb} /{ }^{207} \mathrm{~Pb}\right.$ : 2.439-2.488) showing a similar fingerprint to the fine fraction of the Namib Sea Sand (Fig. 3a).

The $\mathrm{Sr}-\mathrm{Nd}$ isotopic ratios from SAF samples measured in this work (Fig. 3b) exhibit two main groups, indicating plausible dust provenance from different source end-members coherent with the geological history of this part of the continent. The isotopic variability in sediment samples derived from the Omaruru and the Kuiseb riverbeds is large $\left({ }^{87} \mathrm{Sr} /{ }^{86} \mathrm{Sr}=0.7208\right.$ to 0.7384 and $\varepsilon \operatorname{Nd}(0)=-12.80$ to -10.17$)$. In contrast, the Namibia Sand Sea samples depict an even broader range of isotopic values: ${ }^{87} \mathrm{Sr} /{ }^{86} \mathrm{Sr}=0.7128-0.7305$ and $\varepsilon \mathrm{Nd}(0)=-10.39$ to -9.84 , reflecting provenance from the granitic intrusions of the Damara belt (e.g. Miller, 2008). The Huab riverbed, which drains the Paleoproterozoic basement of the Kaoko belt (Goscombe et al., $2003)$, is restricted to a narrower range of isotopic values: ${ }^{87} \mathrm{Sr} /{ }^{86} \mathrm{Sr}=0.725-0.728$ and $\varepsilon \mathrm{Nd}(0)$ $=-18$ to -15 . We also observe a $\mathrm{Nd}$ isotopic trend with values becoming progressively more radiogenic from north to south. This is, the Huab region (in the north of the Namib coastline), exhibits the less radiogenic $\mathrm{Nd}$ composition with $\varepsilon \mathrm{Nd}(0)$ between -18 and -15 , continuing towards the Omaruru and Kuiseb valleys with intermediate $\mathrm{Nd}$ compositions before reaching the southernmost location of the Namibia sand sea region which exhibits $\varepsilon N d$ values between -10.5 and -8 .

\subsection{Grain-Size isotopic fractionation}

Attributable to different mineral contributions, mainly clays and feldspars, that are ultimately controlled by mineral sorting processes (e.g., Garçon et al. 2014), it is observed that the finegrained fractions show a more-radiogenic signature compared to the bulk of the same samples. In the present study, the set of samples from the Huab and Namibia sand sea regions analyzed in the bulk and the fine fractions, conforms to the longstanding observation that there are statistically significant differences in ${ }^{87} \mathrm{Sr} /{ }^{86} \mathrm{Sr}$, but much less so for $\varepsilon \mathrm{Nd}(0)$ and $\mathrm{Pb}$ isotopic values, when comparing the fine and bulk grain-size fractions of these sediments (Figs. 3a, b). While the Namibia Sand Sea samples show the highest Sr isotopic differences $\left(\Delta^{87} \mathrm{Sr} /{ }^{86} \mathrm{Sr} \sim\right.$ 0.012 units), the Huab region difference is limited to only $\sim 0.002$ units (Fig. 3b). Furthermore, for both areas the mean difference between $\varepsilon \operatorname{Nd}(0)$ values for the fine and bulk fractions is $<1 \varepsilon$ units and not significant. For Lead, these differences are also small $\left(\Delta{ }^{206} \mathrm{~Pb} /{ }^{207} \mathrm{~Pb}\right.$ and 
${ }^{208} \mathrm{~Pb} /{ }^{207} \mathrm{~Pb} \sim 0.022$ units for Namib Sand Sea samples and, even smaller $\Delta$ for the Huab samples: 0.01 units) meaning that the sorting by size, although not a zero effect, does not play a significant role that could complicate attempts to relate the $\mathrm{Pb}$ isotope data in remote locations to PSAs. Overall, our results agree with the observed small differences between clay and silt for grain-size fractions in river sediments (e.g. Bayon et al., 2015). The new data presented here corresponding to the finer fraction of Southern Africa sediments agrees with the previous $\mathrm{Pb}$ isotopic ratios $(\mathrm{n}=2)$ reported by Vallelonga et al. (2010) for the same region. Surprisingly, the strontium isotope ratios previously presented in Delmonte et al. (2004a) for this area, are slightly less radiogenic in ${ }^{87} \mathrm{Sr} /{ }^{86} \mathrm{Sr}$ compared with the new values obtained here for the same samples (Fig. 3b). Despite the disparity, this does not affect our interpretations and any difference in the Srisotopic data between the bulk and the fine grain-size fractions of sediments are small compared to the variability of the whole Southern Africa region, reinforcing the hypothesis that the isotopic signatures can be used to fingerprint provenance.

\section{Discussion}

During the late Quaternary, an enhance in continental windblown dust production triggered by the expansion of outwash plains and exposed land areas in general, led to higher dust fluxes during glacial periods. For over three decades, $\mathrm{Sr}-\mathrm{Nd}-\mathrm{Pb}$ isotopes in combination with chemical, physical, and modeled studies have focused on the provenance of dust recovered from East Antarctica ice cores. In this sense, compelling evidence has attributed Southern South America as the primary source of dust to Antarctica during both, cold and warmer periods (e.g. Basile et al., 1997; Delmonte et al., 2004a; Gaiero et al., 2007; Gili et al., 2016, 2017; Albani et al., 2021; Li et al., 2008). Nevertheless, the contribution from other areas in the Southern Hemisphere is still unclear due to the inability to discriminate each individual PSAs because the significant overlap between the different geochemical fingerprints. This matter has kept most of the attention on determining whether if possible to distinguish these different dust signatures and possibly overlooked other important secondary contributions, as is the case of Southern Africa. Even still there is no consensus on whether these PSAs (SSA, AUS, and NZ) should be considered and/or excluded as the dust supplier to EA during the Holocene; here we adhere to the observations of previous studies suggesting that neither AUS or NZ are relevant sources to explain the signature of dust found in East Antarctica (Gili et al., 2016, 2017; Koffman et al., 2021), and therefore have not been taken into account in the present 
discussion. In contrast, we provide compiling evidence in favor of SAF as an important PSA contributing dust to the high-latitude atmosphere and ocean.

\subsection{Southern Africa (SAF) and Southern South America (SSA) fingerprints}

The SAF and SSA signatures can be partially discriminated by combining trace elements (REE) with isotope data (Fig. 4). In general, SAF dust sources evidence low radiogenic Nd (with $\varepsilon \mathrm{Nd}$ values lower than -10), and more radiogenic values of ${ }^{206} \mathrm{~Pb} /{ }^{204} \mathrm{~Pb}$, reflecting the signature of the Damara basement (Figs. 4a, b). In terms of REE, Huab and Kuiseb sediments exhibit an average $\mathrm{Eu} / \mathrm{Eu}^{*}<1$, while Omaruru appears divided in two groups of samples; one following the same trend with $\mathrm{Eu} / \mathrm{Eu}^{*}<1$ and another group with scattered data, showing higher values of $\mathrm{Eu} / \mathrm{Eu}^{*}$ (Fig.4a). Contrarily, SSA exhibits a fingerprint that varies from more "mafic-like" compositions from Patagonia, reflected by Eu/ Eu* values $>1$, higher ${ }^{143} \mathrm{Nd} /{ }^{144} \mathrm{Nd}$ and low ${ }^{206} \mathrm{~Pb} /{ }^{204} \mathrm{~Pb}$, in contrast with more "crustal-like" compositions of material from the Puna-Altiplano Plateau area (Gili et al., 2017; 2016) (Figs.4a, b). For the Namibia sand sea region, only one data point for a bulk sample is available in terms of REE and its composition is similar to the Huab area (Figs. 2a, b). In terms of ${ }^{143} \mathrm{Nd} /{ }^{144} \mathrm{Nd}$ and ${ }^{206} \mathrm{~Pb} /{ }^{204} \mathrm{~Pb}$ isotope ratios, the Namibia sand sea reveals a similarity with some areas of SSA, overlapping with the Southern Altiplano and Northern Puna isotopic composition field (Fig.4b).

\subsection{Southern Africa fingerprint in High-Latitude Environments}

Based on Sr-Nd-Pb isotopes, only two earlier studies (i.e., Delmonte et al. (2004a) and Vallelonga et al. (2010)) suggested the possibility of SAF as a PSA to the polar Antarctic regions. However, due to the limited number of sediment samples and their different signature with respect to EA, they concluded isotopic data was not enough to support a dust contribution from SAF, excluding this region from the provenance puzzle. Contrarily, the new and expanded dataset of Southern Africa $\mathrm{Sr}-\mathrm{Nd}-\mathrm{Pb}$ isotopic ratios and REE concentrations presented in this study indicate that, SAF emerges as PSA that together with high-latitudes sources in Southern South America (that is, the Puna-Altiplano Plateau) can explain the interglacial dust signature found in East Antarctica ice cores, as well as the signature of marine sediments from the South Atlantic sector of the Southern Ocean (Fig. 5).

In general, the ${ }^{87} \mathrm{Sr} /{ }^{86} \mathrm{Sr}$ and $\varepsilon \mathrm{Nd}(0)$ values are more diagnostic than the ${ }^{206,}{ }^{208} \mathrm{~Pb} /{ }^{207} \mathrm{~Pb}$ for identifying the glacial/interglacial dust provenance in paleo-archives. This means that even though the $\mathrm{Pb}$ isotopic data is usually less indicative because of the $\mathrm{Pb}$ input related to local (Antarctic) volcanoes in comparison to the dust related $\mathrm{Pb}$ (Vallelonga et al., 2010), the $\mathrm{Pb}$ data 
in the present study add critical support to our interpretations. This is, the new $\mathrm{Pb}$ isotope data of SAF samples define a field that can account for the entire range of $\mathrm{Pb}$ isotopic compositions observed in the Antarctic dust from Vostok and $\mathrm{EDC}\left({ }^{208} \mathrm{~Pb} /{ }^{207} \mathrm{~Pb}\right.$ values from 2.44-2.50) (Fig. 5a). It should also be noticed that the very radiogenic $\mathrm{Pb}$ data similar to Kuiseb field are also those of the Antarctic local volcanoes (Mt. Erebus); contribution that has been recognized in previous studies (e.g., Hinkley, 2007; Vallelonga et al., 2010; Gili et a., 2016) and cannot be denied. Our results show that EA dust samples show two main compositional trends (orange dashed lines in Figure 5a): $i$ ) the Namibia Sea Sand in combination with a more radiogenic end-member, that is, either Kuiseb PSA or the local Antarctic volcanism and, $i i)$ as suggested by Gili et al. (2016), Patagonian dust plus a McMurdo-Erebus volcanic contribution. In conclusion, Antarctic $\mathrm{Pb}$ dust data fall on a compositional line where a mix of SAF and SSA with a local volcanic end-member could explain the EA dust fingerprint.

This is also in part supported by $\mathrm{Sr}$ and $\mathrm{Nd}$ isotopic data (Figs. 5b, c), where the new SAF defines a compositional field that turns out to be a key end-member for describing the composition of dust deposited in the South Atlantic and EA. In general, during the last glacial climatic periods of the last Quaternary, EA data is very uniform converging to an unequivocal signature from Patagonia with additional inputs from other lower latitude areas in SSA, such as, the Southern Central Western Argentina and Southern Puna (Fig.5b) (Gili et al. (2017) and references therein). On the other hand, the EA interglacial dust fingerprint, as well as the glacial/interglacial signature of marine sediments from the South Atlantic are marked by a variable mix of sources (Fig. 5b). An important finding of this study is that a tri-mixing hyperbola with common end-members can be drawn and help to decipher this variability. This is, the best candidates to elucidate the origin of dust during the Holocene and likely during the last $15 \mathrm{ka}$ are a more mafic-like end-member represented by Patagonia and/or SCWA, in addition to a second crustal-like end-member, defined by the Southern Altiplano, plus a third end-member, which can either be the northern Puna (black solid line) or Southern Africa (dotted black line) and/or a mix of these two (Fig. 5c, Table S2). This is also in agreement with the isotopic composition of present-day dust deposited on the Berkner Island in the Atlantic sector of coastal Antarctica, which can clearly be ascribed to a mixing isotopic composition from PAP (Bory et al., 2010; Gili et al., 2017) and SAF PSAs (Fig.5c). In this sense, Bory et al. (2010) pointed out that neither of the PSAs in SSA could account for the entire Sr-Nd isotopic range of the dust deposited on Berkner and the contribution of another secondary source with more negative $\varepsilon N d(0)$ was missing. The $\mathrm{Sr}$ and $\mathrm{Nd}$ signature of the SAF samples presented here can account for that 'missing' end-member. Alike, Noble et al. (2012), indicated 
the signature identified in ocean sediments from the South Atlantic is associated with material derived from SAF, but also with compositions similar to the northern-Puna (Fig.5b, c). Aeolian dust blown from the Namibian region by the SE trade winds is considered one of the main sources of detritus to the South Atlantic Ocean (e.g., Dieckmann et al., 1996). In this sense, interglacial detrital fractions recovered from marine cores from the SE Atlantic region display $\varepsilon N d(0)$ values between -10 and -22 that have been attributed to a Southern Africa origin (Bayon et al., 2003), which is also in accordance with the SAF Nd isotopic data presented here. As presented by the evidences above and as seen in Fig. 5, the composition of interglacial and present-day dust deposited in East Antarctica and the South Atlantic ocean can be explained by the mixing between Patagonia, the Puna-Altiplano Plateau and Southern Africa, although the distinction and relative contribution from the different PAP and SAF source areas remains puzzling. It should also be noted that the SAF source becomes more important in the SO and marginal sites of EA where the SSA signature is not enough to justify the data, although local Antarctic sources may also play a role. The similar geochemical composition exhibited by these two areas (i.e. SAF and the PAP) could be related to the comparable climatological aspects that the Puna-Altiplano Plateau and Southwestern Africa share from their tropical to sub-tropical location (between about $17^{\circ}$ and $30^{\circ} \mathrm{S}$ latitude) (Tyson, 1986). Both regions are influenced by atmospheric circulation dominated by subsidence air zones (SE Atlantic-Namibia- and SE Pacific -PAP-), promoting extreme arid conditions and producing the world's desert lands. Reinforcing the aridity in these areas is the presence of an upwelling, north-flowing, cold oceanic current; the Humboldt along the west coast of South America and the Benguela along western South Africa. Precipitation is the result of tropical convection and rainfall patterns are controlled by the South American summer monsoon (SASM) and East African summer monsoon (EASM), respectively. Both areas have shown important climatic variability during the late Quaternary, indicating altering cycles of wet/dry conditions, however interpretations about the main factors determining these changes is still controversial. Some authors have pointed to a precessional orbital control after finding a correlation between periods of Southern Hemisphere maximum insolation and enhancement of moist air on land, increasing precipitation delivered by the SASM and EASM (Baker et al., 2001; Fritz et al., 2004; Partridge et al., 1997). Others have suggested that southwestern Africa responds to variations in phase with the Northern Hemisphere summer insolation (e.g., Chase et al., 2009). Despite the debate of these complex mechanisms, there is persuasive evidence supporting the important role of both the PAP and SAF regions as dust suppliers during the late Quaternary. The arid and dry environmental conditions in Namibia have been similar to what it is today for the last $50 \mathrm{Ky}$, 
407

408

409

410

411

412

413

414

415

416

417

418

419

420

421

422

423

424

425

426

427

428

429

430

431

432

433

434

435

436

437

438

439

440

with the late Holocene being the driest period (Chase et al. (2019) and references therein). Based on a pollen marine record, Shi et al. (2000) indicated two arid peak periods (14-12 Ky and 11-9 Ky) for the early Holocene in this part of the Southern Africa continent. Authors suggested a northward migration (from its present position) of the intertropical convergence zone (ITZC) resulted in a reduction of the water vapor supply in southern subtropical Africa during the early Holocene. A marine grain-size record (Stuut et al., 2002) and a collection of terrestrial records (Chase and Meadows, 2007) also suggested arid conditions in southern Africa during interglacial stages due to meridional shifts in the atmospheric circulation system. These authors indicated intensified trade-winds during glacials compared to interglacials. Depleted isotopes in precipitation have also pointed out to dry conditions during warm periods (Collins et al., 2014). In line with this, a more recent pollen record from the southern Namib Desert obtained from rock hyrax middens have shown the Holocene was a time were high temperatures and evapotranspiration resulted in increased aridity and an expansion of the desert vegetation (Lim et al., 2016). These environmental conditions of dryness during interglacial times are also indicated for the PAP area (see details in Gili et al., 2017), especially during the Holocene (Fornace et al., 2014) and MIS 5.5 (Baker and Fritz, 2015). In addition, a combined grain-size study of two marine cores taken off the coast of southwestern Africa ( 20S) and western South America ( 27S), observed both sites showed arid conditions for at least the last 35,000 years (Stuut and Lamy, 2004).

\subsection{Atmospheric circulation pattern and dust deposition over Antarctica}

While the geochemical evidences presented here, demonstrate that SAF sediments have a dust signature comparable with the interglacial and modern dust deposited in different environments of the $\mathrm{SH}$, the concept about how the transport occurs from the Namibian coastal regions to Antarctica is still not well known. The deposition of dust around Antarctica can happen by either a scenario whereby it is deposited in the interior high elevation sites or in the periphery low elevation sites of the Antarctic plateau (e.g., Delmonte et al., 2008). Mineral dust reaching the EA plateau is windborne long-range transported from the continental land-masses carried through the mid-to high troposphere. For dust sources that are not located at high latitudes, such is the case of SAF, there is need of strong convective uplift of particles up to 200-400 mbar to reach the interior plateau and the presence of SAF particles has mostly been reported in the lower troposphere (Chazette et al., 2019). Another possibility is that the source itself is already elevated in altitude allowing the injection of dust particles directly in the high 
troposphere. This is the case of the Puna-Altiplano Plateau in SSA, where the subtropical jet stream acts as main mechanism mobilizing large amounts of dust that ultimately, get deposited onto the polar plateau (Gili et al., 2017; Gaiero, 2007; Gaiero et al., 2013) and whose signal has also been found in peripheric areas of Antarctica (Bory et al., 2010). Although a significant dust emission source, modeling data has suggested that material from SAF only contributes with $\sim 5 \%$ of the total dust burden over Antarctica, mostly because the emissions are localized near the source, and a southward transport to the inner part of the Antarctic continent is unlike (Albani et al., 2012; Li et al., 2008). However, modeled dust emission fluxes from the different PSAs of the SH and their subsequent deposition driven by the local trade winds, can vary by as much as a factor of four or more (Neff and Bettler, 2015), which could mislead to controversial interpretations. In this sense, comparatively with the study of Neff and Butler (2015), who indicated that even in small amounts SAF dust could be found in East Antarctica, a more recent global model simulation indicated that together with SSA, that accounts for almost the bulk of the deposited dust, Southern Africa represents a secondary source that contributes to the total dust deposition flux to Antarctica (Kok et al., 2021). Similar observations have also been highlighted for the Southern Ocean. Using HYSPLIT, a trajectory model, Bhattachan et al. (2012) showed that dust emissions from the Southern Kalahari commonly reaches the Southern Ocean, with most of the trajectories traveling beyond $40^{\circ} \mathrm{S}$ during the dry period (April-September) when conditions favor the dust production and transportation (Bryant et al., 2007).

We note however, that most of the regional to global dust models regarding Namibian sources are solely based on the atmospheric circulation of the trade winds to emit dust. While in reality, it is the Berg winds, a local southwestern Africa topographically enhanced thermal wind that represents a more important mechanism responsible of dust mobilization and deposition over the ocean (Vickery and Eckardt, 2013; Todd and Washington, 1999). These hot and dry winds are also more common in winter and they are the result of adiabatic heating; a process that occurs when air coming from the escarpment and plateaus descending towards the Namibian coastline, where it is compressed and heated. Multiple dust streams and dust storms originated in this part of the African continent evidencing the substantial transport of material to the Southern Ocean as a result of Berg winds have been spotted by different satellite platforms (Von Holdt et al., 2017; Vickery and Eckardt, 2013). This has important implications for the transportation of material to the marginal and coastal sites of Antarctica, which can receive an unquantified amount of SAF dust. On this matter, more recent studies have showed strong support that highlights Southern Africa as a secondary and significant dust supplier to East 
475 Antarctica. Gili et al. (2019), indicated the $\mathrm{Sr}, \mathrm{Nd}$ and $\mathrm{Pb}$ isotope ratios of Antarctic modern 476 dust recovered from snow samples collected along coastal sites of the Dronning-Maud Land 477 area (DML-East Antarctica), which showed similar composition to the Southern Africa 478 sediments. This data is consistent with the results observed by Vanderstraeten et al. (2019), in 479 a back trajectory FLEXPART particle dispersion transport model where a mix of modern 480 Southern Africa and Southern South America sources was clearly spotted in the coastal area of 481 East Antarctica. Likewise, using a statistical analyses Vanderstraeten et al. (2021) revisited the only EDML ice core rare earth elements dataset available from Wegner et al. (2012), and observed that the Southern Africa fingerprint appears at $\sim 15 \mathrm{kyr}$ as an important mixing endmember that together with SSA, can explain the East Antarctica interglacial dust signature. Ultimately, another study carried out in a core from the Southern Indian Ocean, has also proposed a mixing model where SSA and SAF have been found to be the main distal dust sources through most of the Holocene (Li et al., 2020). In resume, we have presented different evidences indicating the transport of SAF material reaches the South Atlantic sector of the Southern Ocean and the marginal sites of East Antarctica. Thus, one could infer that the same material could also be transported farther distances and ultimately get deposited in the interior of the polar plateau. However, more modeling studies are necessary to fully prove this type of transportation.

493

\section{Conclusions}

495

Because wind-borne minerals are strongly linked to atmospheric dynamics, the 497 characterization of present-day Southern African dust and its potential sources is useful for the interpretation of paleo-records. Improving our knowledge about the dust cycle in the Southern Hemisphere can provide important information about atmospheric circulation patterns during the last climatic cycles. This study represents a step forward in the documentation of aeolian dust sources in SAF. We have combined chemical and isotopic data to characterize for the first time the main desert areas along the Namibian coast, a potential dust source area, whose contribution to the high-latitude environments of the SH has been underestimated, mostly due to the lack of SAF data from suitable samples. Here, we have compared the rare earth elements concentrations and $\mathrm{Sr}-\mathrm{Nd}-\mathrm{Pb}$ isotopes of SAF PSAs with those indicated as the main dust sources to the Southern Ocean and Antarctica during glacial and interglacial periods. Our results show that the Huab, Omaruru, Kuiseb, and the Namibia sand sea regions in SAF, denote 
509

510

511

512

513

514

515

516

517

518

519

520

521

522

523

524

525

526

527

528

529

530

531

532

533

534

535

536

537

538

539

540

541

542

SAF fingerprints match very well with the composition of interglacial sediments deposited in the SO and EA. However, a distinction of which areas are more dominant remains challenging, which can be related to the common position of these regions in subsidence air zones within the SE Pacific and SE Atlantic anticyclones. This characteristic is also responsible for the extreme aridity conditions that characterize both regions in the present climate and that has also been observed during warm times, especially the Holocene.

In summary, this study agrees with previous findings suggesting that SSA is the best candidate to explain the dust signature recorded in the SO and EA during cold and warm stages. For interglacial periods, this work proposes a scheme where the typical isotopic variability observed in interglacial and present-day dust sediments deposited in the South Atlantic Ocean and East Antarctica can be related to the contributions of two main PSAs: Southern South America, through westerlies dominating the atmospheric circulation over Patagonia and SCWA and, the jet stream over PAP, in combination with Southern Africa in response to the plausible transport by strong Berg winds. More modeling studies focusing on the atmospheric mechanisms responsible for the combined mix of air masses depositing dust over these highlatitude environments are immensely needed. Westerly winds and subtropical jet stream atmospheric currents have been extensively indicated as the responsible for the Patagonia/SCWA and PAP signatures, respectively (Gili et al. (2017) and references therein). For the Namibia region, while Berg winds account for the dust load deposited in the South Atlantic (Shannon and Anderson, 1982), the extent of this transport to higher latitude areas, such as, the East Antarctic plateau is still unknown. Likewise, more mineralogical and geochemical studies focusing on the PAP and SAF PSAs will allow to gain a better understanding of the similarity between the regions and ultimately help to improve our knowledge about major atmospheric circulation patterns that occurred during the last glacialinterglacial cycles in the Southern Hemisphere.

\section{Acknowledgments}

This work was supported through Belgian Federal Science Policy Office (BELSPO) fellowship (Convention BR/175/A2/CHASE 1\&2). Co-authors would like to warmly thank Jeroen De Jong (ULB) for their assistance during isotopic analyses. CNRS-INSU is gratefully acknowledged for supporting CESAM as an open facility through the National Instrument and AERIS datacenter (aeris-data.fr) for hosting simulation chamber data. The CESAM chamber has received funding from the European Union's Horizon 2020 research and innovation 
543 program through the EUROCHAMP-2020 Infrastructure Activity under grant agreement No.

544 730997. Sample collection was supported by the Natural Science and Engineering Research

545 Council of Canada (Discovery Grant RGPIN-2016-05417).

\section{$546 \quad$ Figures}

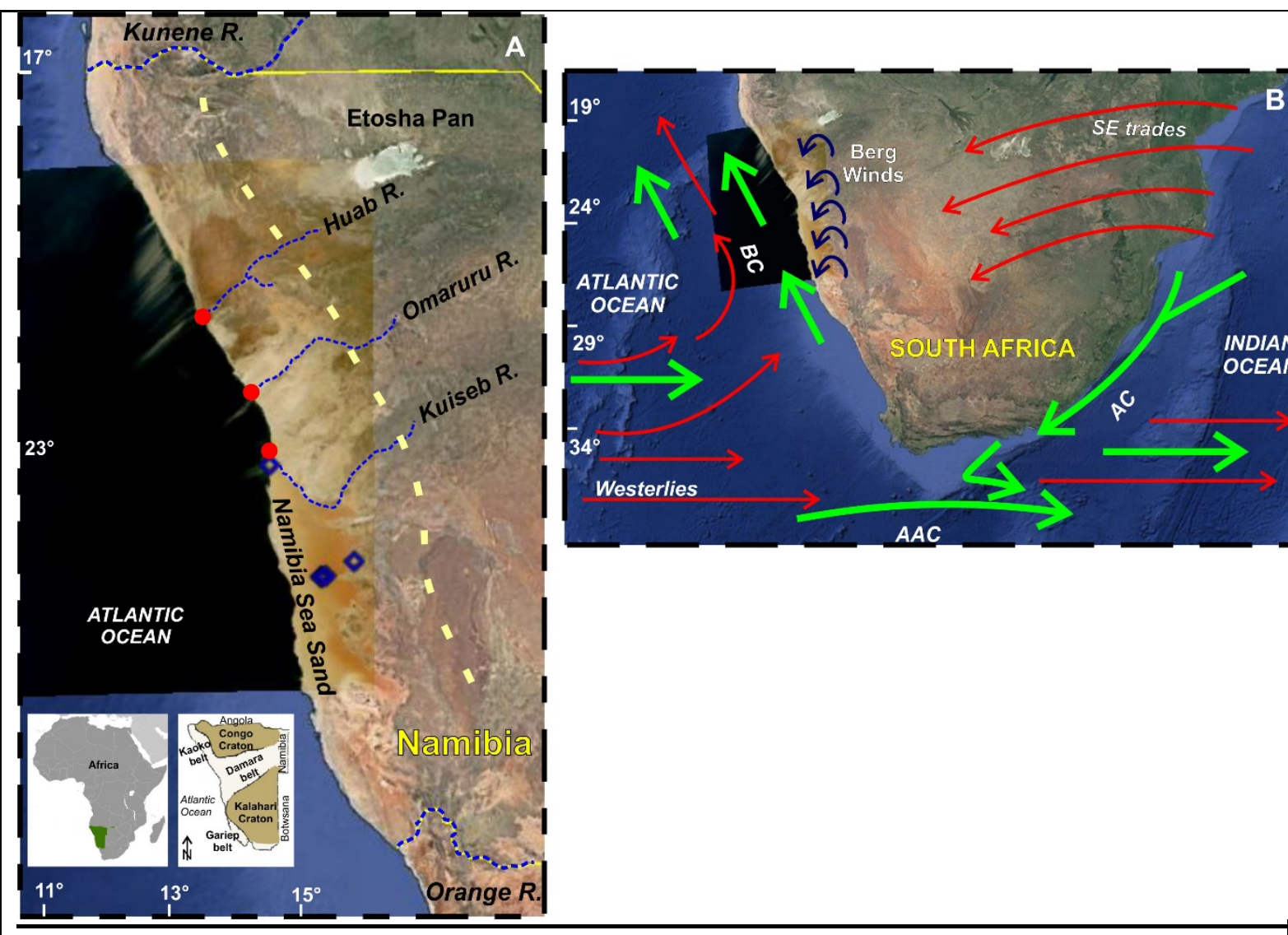

Figure 1: Left panel (A): Southern Africa Potential dust Potential Source Areas characterized in this study: Huab, Omaruru, Kuiseb (red dots) and the Nambia Sea Sand (blue diamonds). A satellite image of dust plumes originated off the coast in SAF detected by MODIS on 29 July 2015 are also showed and available at NASA Worldview. The hydrographic Huab, Omaruru and Kuiseb systems are indicated by the blue lines. Right panel (B): map pf southwestern Africa showing the major features of the regional climate system. Main oceanic currents are indicated in bold green arrows and atmospheric circulations in red (south easterly trade and westerlies winds) and blue (Berg winds). BC: Benguela Current; ACC: Antarctic Circumpolar Current; AC: Aghulas Current. 


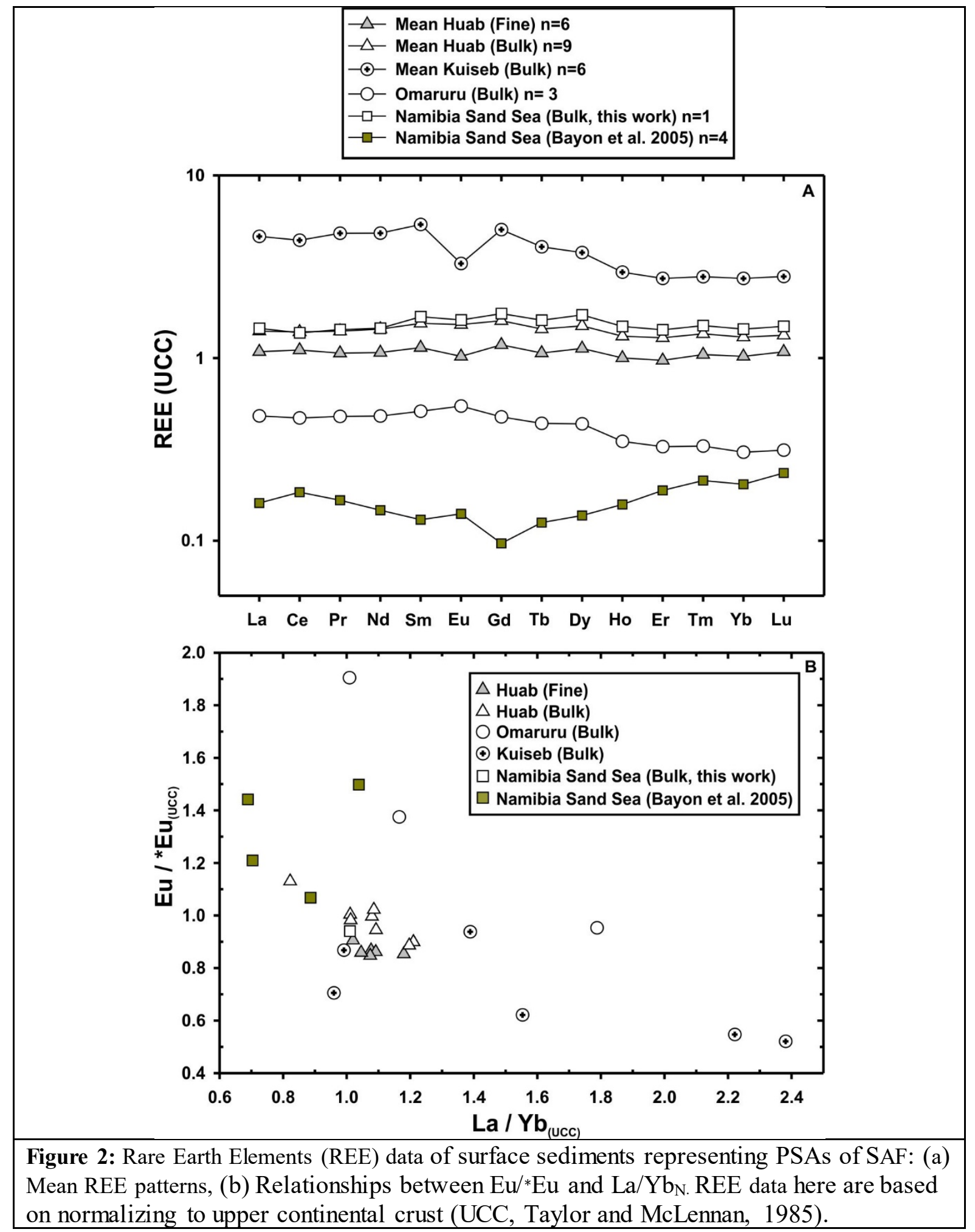




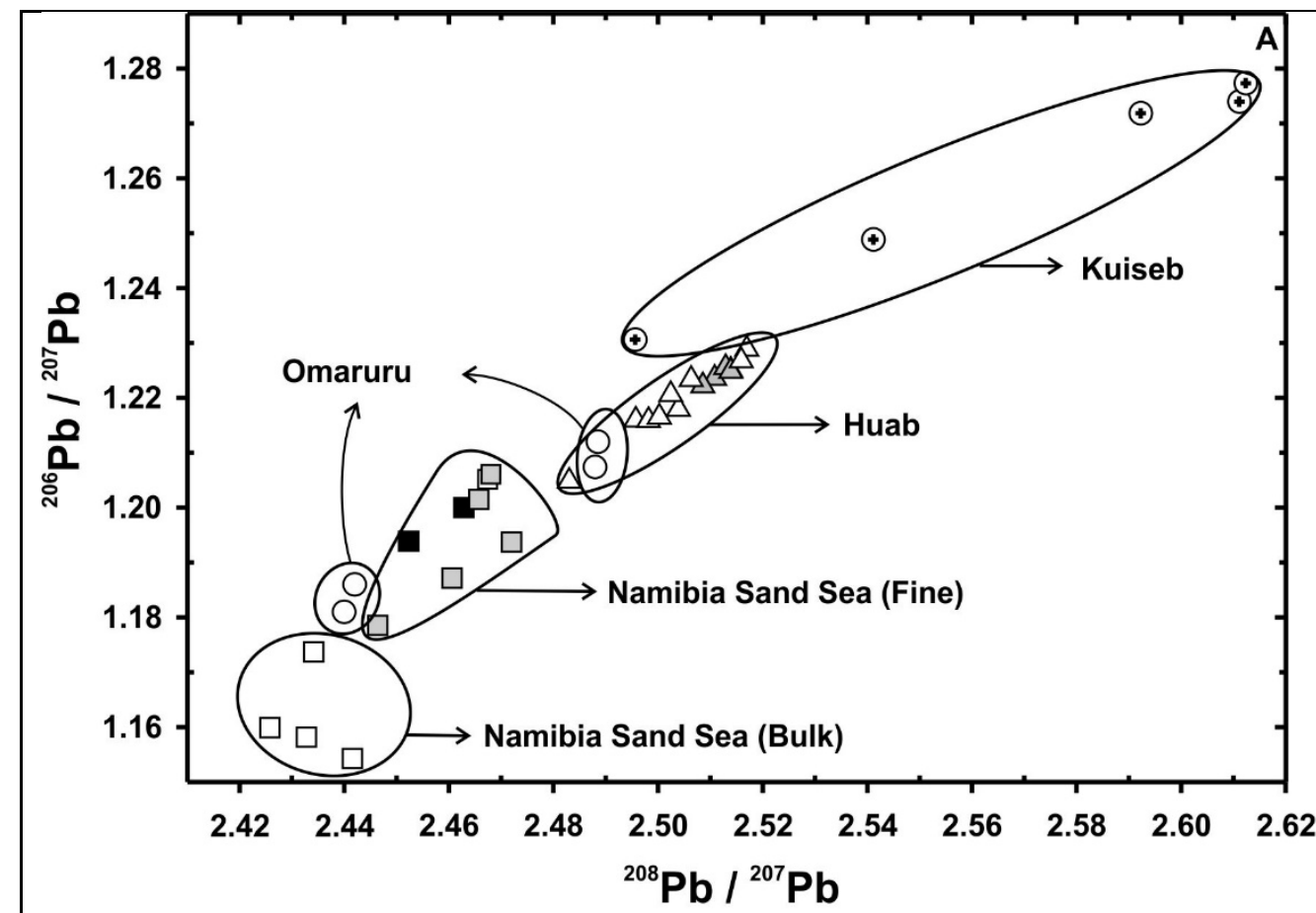

$\triangle$ Huab (Fine)

$\triangle$ Huab (Bulk)

$\bigcirc$ Omaruru (Bulk)

๑) Kuiseb (Bulk)

$\square$ Namibia Sand Sea (Bulk, this work)

$\square$ Namibia Sand Sea (Fine, this work)

Namibia Sand Sea (Fine, Vallelonga et al. 2004; Delmonte et al. 2004a)

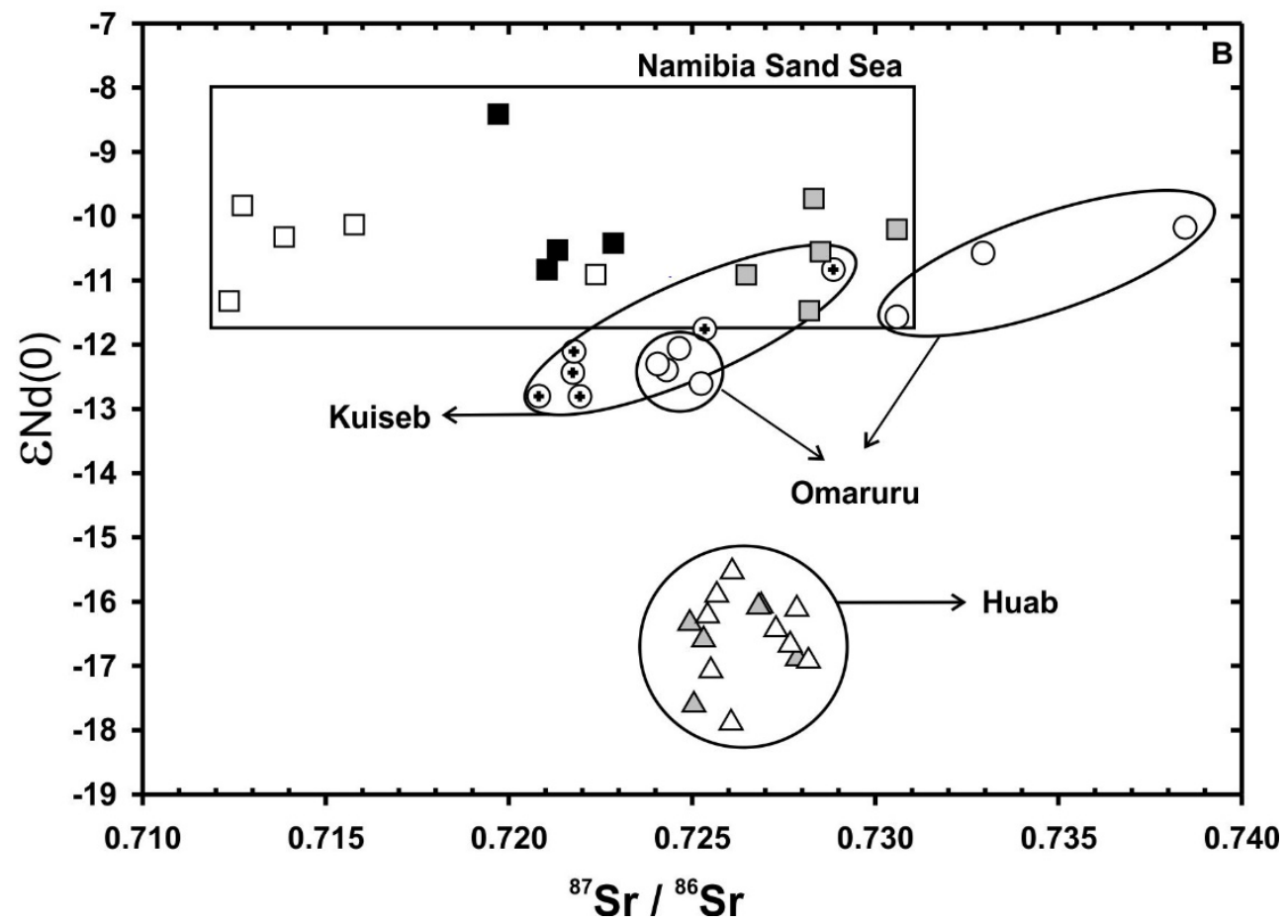

Figure 3: $\mathrm{Sr}-\mathrm{Nd}-\mathrm{Pb}$ isotopic compositions of SAF sediments. (a) ${ }^{208} \mathrm{~Pb} /{ }^{207} \mathrm{~Pb}$ vs. ${ }^{206} \mathrm{~Pb} /{ }^{207} \mathrm{~Pb}$ (b) ${ }^{87} \mathrm{Sr} /{ }^{86} \mathrm{Sr}$ vs. $\varepsilon \mathrm{Nd}(0)$. Grain size effects on $\mathrm{Sr}-\mathrm{Nd}-\mathrm{Pb}$ isotopic compositions for the Huab and Namibia sand sea are also shown and indicated by symbols in gray (fine) and open symbol (bulk). 

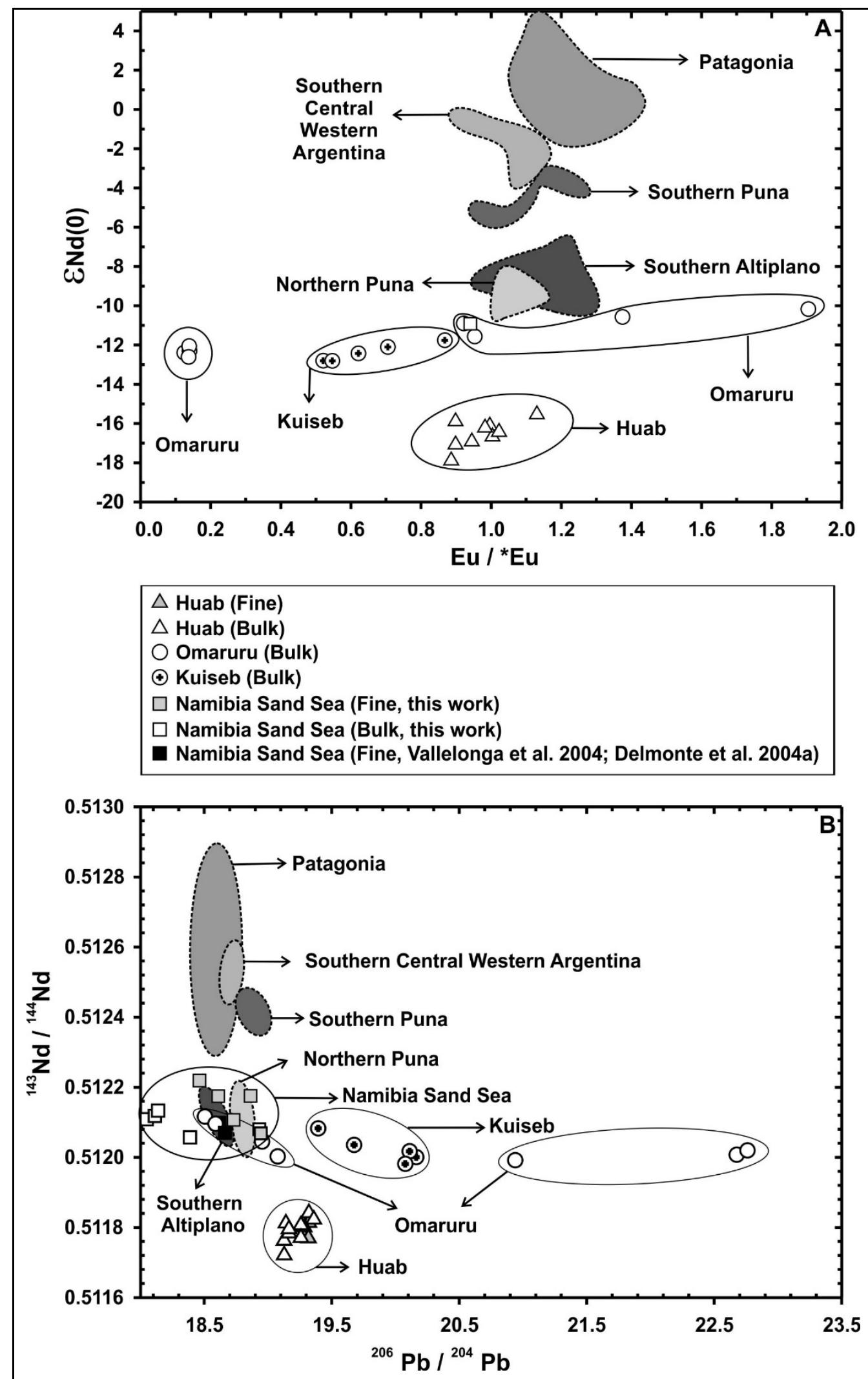

Figure 4: Comparison of SAF and SSA geochemical signature. (a) $\mathrm{Eu} /{ }^{*} \mathrm{Eu}$ vs. $\varepsilon \mathrm{Nd}(0)$, (b) ${ }^{206} \mathrm{~Pb} /{ }^{204} \mathrm{~Pb}$ vs. ${ }^{143} \mathrm{Nd} /{ }^{144} \mathrm{Nd}$. 


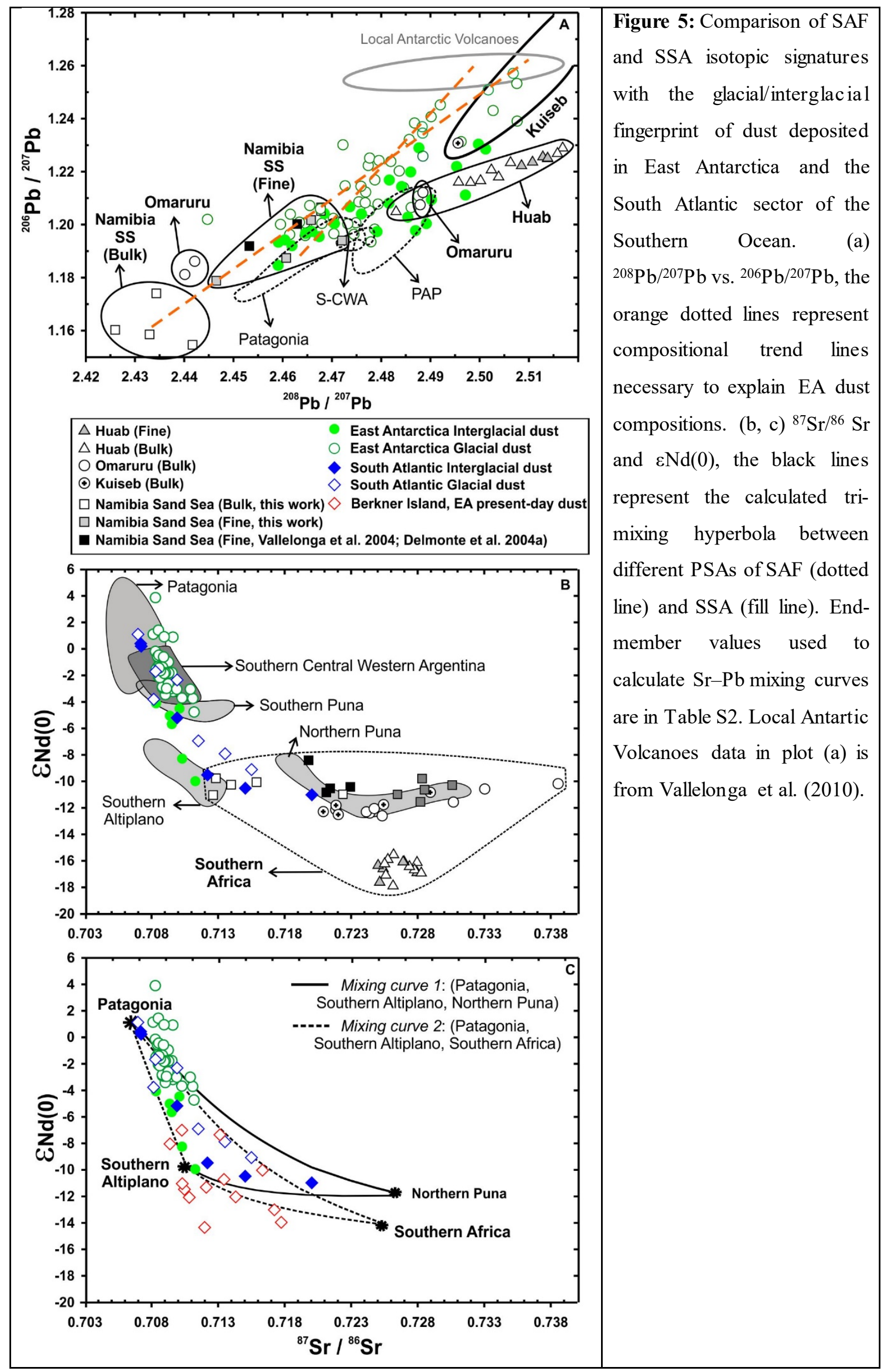


Albani, S., Delmonte, B., Maggi, V., Baroni, C., Petit, J.-R., Stenni, B., Mazzola, C., Frezzotti, M. (2012) Interpreting last glacial to Holocene dust changes at Talos Dome (East Antarctica): implications for atmospheric variations from regional to hemispheric scales. Climate of the Past 8, 741-750.

Baker, P.A., Fritz, S.C., 2015. Nature and causes of Quaternary climate variation of tropical South America. Quat. Sci. Rev.124, 31-47.

Baker, P.A., Rigsby, C.A., Seltzer, G.O., Fritz, S.C., Lowenstein, T.K., Bacher, N.P., Veliz, C., 2001a. Tropical climate changes at millennial and orbital timescales in the Bolivian Altiplano. Nature 409, 698e701.

Basile, I., Grousset, F.E., Revel, M., Petit, J.R., Biscaye, P.E., Barkov, N.I. (1997) Patagonian origin of glacial dust deposited in East Antarctica (Vostok and Dome C) during glacial stages 2, 4 and 6. Earth and Planetary Science Letters 146, 573-589.

Bayon, G., Toucanne, S., Skonieczny, C., André, L., Bermell, S., Cheron, S., Dennielou, B., Etoubleau, J., Freslon, N., Gauchery, T., Germain, Y., Jorry, S.J., Ménot, G., Monin, L., Ponzevera, E., Rouget, M.-L., Tachikawa, K., Barrat, J.A., 2015. Rare earth elements and neodymium isotopes in world river sediments revisited. Geochim. Cosmochim. Acta 170, 17-38.

Bayon G., German C. R., Burton K. W., Nesbitt R. W. and Rogers N. (2005) Sedimentary $\mathrm{Fe}-\mathrm{Mn}$ oxyhydroxides as paleoceanographic archives and the role of aeolian flux in regulating oceanic dissolved REE. Earth Planet. Sci. Lett. 224,477-492.

Bhattachan, A., D’Odorico, P., Baddock, M.C., Zobeck, T.M., Okin, G.S. and Cassar, N., 2012. The Southern Kalahari: a potential new dust source in the Southern Hemisphere?. Environmental Research Letters, 7(2), p.024001.

Bryant, R.G., 2003. Monitoring hydrological controls on dust emissions: preliminary observations from Etosha Pan, Namibia. Geographical Journal, 169(2), pp.131-141.

Bryant, R. G., Bigg, G.R, Mahowald, N.M., Eckardt, F.D. and Ross, S.G. (2007) Dust emission response to climate in Southern Africa J. Geophys. Res. 112 D09207

Chase, B.M., Meadows, M.E. (2007) Late Quaternary dynamics of southern Africa's winter rainfall zone. Earth-Science Reviews 84, 103-138.

Chase, B. M., Boom, A., Carr, A. S., Chevalier, M., Quick, L. J., Verboom, G. A., and Reimer, P. J. (2019) Extreme hydroclimate response gradients within the western Cape Floristic region of South Africa since the Last Glacial Maximum, Quaternary Science Reviews, 219, 297-307

Chazette, P., Flamant, C., Totems, J., Gaetani, M., Smith, G., Baron, A., Landsheere, X., Desboeufs, K., Doussin, J.-F., and Formenti, P.: Evidence of the complexity of aerosol transport in the lower troposphere on the Namibian coast during AEROCLO-sA, Atmos. Chem. Phys., 19, 1497915005, https://doi.org/10.5194/acp-19-14979-2019, 2019.De Deckker, P. (2019) An evaluation of Australia as a major source of dust. Earth-Science Reviews 194, 536-567.

Collins, J. A. , Schefuß, E. , Govin, A. , Mulitza, S. and Tiedemann, R. (2014): Insolation and glacial-interglacial control on southwestern African hydroclimate over the past 140000 years, Earth and Planetary Science Letters, 398 , pp. 1-10 . doi: 10.1016/j.epsl.2014.04.034

Compton JS, Herbert CT, Hoffman MT, Schneider RR, Stuut J-B. A tenfold increase in the Orange River mean Holocene mud flux: implications for soil erosion in South Africa. The Holocene. 2010;20(1):115-122.

De Deckker, P., Norman, M., Goodwin, I.D., Wain, A., Gingele, F.X. (2010) Lead isotopic evidence for an Australian source of aeolian dust to Antarctica at times over the last 170,000years. Palaeogeography, Palaeoclimatology, Palaeoecology 285, 205-223.

Delmonte, B. et al. (2019) Holocene dust in East Antarctica: Provenance and variability in time and space. The Holocene 095968361987518.

Delmonte, B., Andersson, P.S., Hansson, M., Schöberg, H., Petit, J.R., Basile-Doelsch, I., Maggi, V. (2008) Aeolian dust in East Antarctica (EPICA-Dome C and Vostok): Provenance during glacial ages over the last 800 kyr. Geophysical Research Letters 35, 
Delmonte, B., Andersson, P.S., Schöberg, H., Hansson, M., Petit, J.R., Delmas, R., Gaiero, D.M., Maggi, V., Frezzotti, M. (2010) Geographic provenance of aeolian dust in East Antarctica during Pleistocene glaciations: preliminary results from Talos Dome and comparison with East Antarctic and new Andean ice core data. Quaternary Science Reviews 29, 256-264.

Delmonte, B., Basile-Doelsch, I., Petit, J.-R., Maggi, V., Revel-Rolland, M., Michard, A., Jagoutz, E., Grousset, F. (2004a) Comparing the Epica and Vostok dust records during the last 220,000 years: stratigraphical correlation and provenance in glacial periods. Earth-Science Reviews $66,63-87$.

Diekmann, D., R. Petschick, F. X. Gingele, D. K. Füllerer, A. Abelmann, R. Gersonde, U. Brathauer, and A. Mackensen, Clay mineraI fluctuations in the Late Quaternary sediments of the southeastern Atlantic: Implications for past changes of deepwater advection, in 'The South Atlantic: Present and Past Circulation, edited by G. Wefer, W. H. Berger, G. Siedler, and D. Webb, pp. 621644, Springer-Verlag, New York, 1996.

Du, Z., Xiao, C., Ding, M., Li, C. (2018) Identification of multiple natural and anthropogenic sources of dust in snow from Zhongshan Station to Dome A, East Antarctica. Journal of Glaciology 64, 855-865.

Eckardt, F., Soderberg, K., Coop, L., Muller, A., Vickery, K., Grandin, R., Jack, C., Kapalanga, T., Henschel, J., 2013. The nature of moisture at Gobabeb, in the central Namib Desert. J. Arid Environ. 93, 7-19

Fornace, K.L., Hughen, K.A., Shanahan, T.M., Fritz, S.C., Baker, P.A., Sylva, S.P., 2014. A 60,000-year record of hydrologic variability in the Central Andes from the hydrogen isotopic composition of leaf waxes in Lake Titicaca sediments. Earth Planet. Sci. Lett.408, 263-271.

Fritz, S. C., P. A. Baker, T. Lowenstein, G. O. Seltzer, C. A. Rigsby, G. S. Dwyer, P. M. Tapia, K. K. Arnold, T. L. Ku, and S. Luo (2004), Hydrologic variation during the last 170000 years in the Southern Hemisphere tropics of South America, Quat. Res., 61, 95-104.

Gaiero, D.M. (2007) Dust provenance in Antarctic ice during glacial periods: From where in southern South America? Geophysical Research Letters 34.

Gaiero, D.M., Brunet, F., Probst, J.-L., Depetris, P.J. (2007) A uniform isotopic and chemical signature of dust exported from Patagonia: Rock sources and occurrence in southern environments. Chemical Geology 238, 107-120.

Gaiero, D.M., Depetris, P.J., Probst, J.-L., Bidart, S.M., Leleyter, L. (2004) The signature of river- and wind-borne materials exported from Patagonia to the southern latitudes: a view from REEs and implications for paleoclimatic interpretations. Earth and Planetary Science Letters 219, 357-376.

Gaiero, D.M., Simonella, L., Gassó, S., Gili, S., Stein, A.F., Sosa, P., Becchio, R., Arce, J., Marelli, H. (2013) Ground/satellite observations and atmospheric modeling of dust storms originating in the high Puna-Altiplano deserts (South America): Implications for the interpretation of paleoclimatic archives: DUST STORMS FROM PUNA-ALTIPLANO DESERTS. Journal of Geophysical Research: Atmospheres 118, 3817-3831.

Garçon, M., Chauvel, C., France-Lanord, M., Limonta, M., Garzanti, E., (2014) Which minerals control the $\mathrm{Nd}-\mathrm{Hf}-\mathrm{Sr}-\mathrm{Pb}$ isotopic compositions of river sediments?, Chemical Geology, Volume 364, 2014, Pages 42-55, ISSN 0009-2541, doi.org/10.1016/j.chemgeo.2013.11.018.

Garzanti, E., Vermeesch, P., Andò, S., Lustrino, M., Padoan, M., 2014. Ultra-long distance littoral transport of Orange sand and provenance of the Skeleton Coast Erg (Namibia). Marine Geology 357, 25-36.

Gasse, F., Chalié, F., Vincens, A., Williams, M.A.J., Williamson, D. (2008) Climatic patterns in equatorial and southern Africa from 30,000 to 10,000 years ago reconstructed from terrestrial and near-shore proxy data. Quaternary Science Reviews 27, 2316-2340.

Gili, S., Gaiero, D.M., Goldstein, S.L., Chemale, F., Jweda, J., Kaplan, M.R., Becchio, R.A., Koester, E. (2017) Glacial/interglacial changes of Southern Hemisphere wind circulation from the geochemistry of South American dust. Earth and Planetary Science Letters 469, 98-109.

Gili, S., Gaiero, D.M., Goldstein, S.L., Chemale Jr, F., Koester, E., Jweda, J., Vallelonga, P., Kaplan, M.R. (2016) Provenance of dust to Antarctica: A lead isotopic perspective, Geophysical Research Letters 43, 2291-2298. 
Gili, S., Vanderstraeten, A., Chaput,A., Cazaunau, M., Pangui, E., Di Biagio, C., Doussin, JF., King,J., Formenti,P., and Mattielli, N. (2019) Isotopic evidence ( $\mathrm{Sr}, \mathrm{Nd}$ and $\mathrm{Pb}$ ) of South Africa as a dust precursor for atmospheric depositions in Antarctica, INQUA 2019, p1435.

Goscombe, B.D., Hand, M., Gray, D., 2003a. Structure of the Kaoko Belt, Namibia: progressive evolution of a classic transpressional orogen. J. Struct. Geol. 25, 1049-1081

Grousset, F.E., Biscaye, P.E., Revel, M., Petit, J.-R., Pye, K., Joussaume, S., Jouzel, J. (1992) Antarctic (Dome C) ice-core dust at 18 k.y. B.P.:Isotopic constraints on origins. Earth and Planetary Science Letters 111, 175-182.

Heine, K and Heine, J.T (2002) A paleohydrologic reinterpretation of the Homeb Silts, Kuiseb River, central Namib Desert (Namibia) and paleoclimatic implications, CATENA, Volume 48, Issues 1-2, 107-130, doi.org/10.1016/S0341-8162(02)00012-7.

Jacobs, J., Pisarevsky, S., Thomas, R.J., Becker, T., 2008. The Kalahari Craton during the assembly and dispersal of Rodinia. Precambrian Res. 160, 142-158.

Jacobson, P.J., K.M. Jacobson, and M.K. Seely. 1995. Ephemeral rivers and their catchments: sustaining people and development in western Namibia. Desert Research Foundation of Namibia, Windhoek. 160 pp.

Jickells, T.D. (2005) Global Iron Connections Between Desert Dust, Ocean Biogeochemistry, and Climate. Science 308, 67-71.

Jung, S., and Mezger, K. 2003 "U-Pb garnet chronometry in high-grade rocks — case studies from the central Damara orogen (Namibia) and implications for the interpretation of Sm-Nd garnet ages and the role of high U-Th inclusions." Contributions to Mineralogy and Petrology 146: 382-396

Kohfeld, K.E., Graham, R.M., de Boer, A.M., Sime, L.C., Wolff, E.W., Le Quéré, C., Bopp, L. (2013) Southern Hemisphere westerly wind changes during the Last Glacial Maximum: paleo-data synthesis. Quaternary Science Reviews 68, 76-95.

Koffman, B. G., et al (2021). New Zealand as a source of mineral dust to the atmosphere and ocean, Quaternary Science Reviews, Volume 251, https://doi.org/10.1016/j.quascirev.2020.106659.

Lambert, F. et al. (2008) Dust-climate couplings over the past 800,000 years from the EPICA Dome C ice core. Nature 452, 616-619.

Kok, J.F., A.A. Adebiyi, S. Albani, Y. Balkanski, R. Checa-Garcia, M. Chin, P.R. Colarco, D.S. Hamilton, Y. Huang, A. Ito, M. Klose, L. Li, N.M. Mahowald, R.L. Miller, V. Obiso, C. Pérez García-Pando, A. Rocha-Lima, and J.S. Wan, 2021: Contribution of the world's main dust source regions to the global cycle of desert dust. Atmos. Chem. Phys., 21, no. 10, 8169-8193, doi:10.5194/acp-21-8169-2021.

Lancaster, N. and Ollier, C.D., 1983. Sources of sand for the Namib sand sea. Zeitschrift für Geomorphologie, 45, pp.73-83.

Li, C. et al. (2020) Holocene dynamics of the southern westerly winds over the Indian Ocean inferred from a peat dust deposition record. Quaternary Science Reviews 231, 106169.

Li, F., Ginoux, P., Ramaswamy, V. (2008) Distribution, transport, and deposition of mineral dust in the Southern Ocean and Antarctica: Contribution of major sources. Journal of Geophysical Research 113, D10207.

Lim, S., Chase, B.M., Chevalier, M., Reimer, P.J. (2016) 50,000 years of vegetation and climate change in the southern Namib Desert, Pella, South Africa. Palaeogeography, Palaeoclimatology, Palaeoecology 451, 197-209.

Mahowald, N.M., Bryant, R.G., del Corral, J. and Steinberger, L., 2003. Ephemeral lakes and desert dust sources. Geophysical Research Letters, 30(2).

Miller, R. M. G. (1983), The Pan-African Damara Orogen of South West Africa/Namibia, Geol. Soc. of South Africa, Spec. Publ., 11, 431- 515.

Miller, R. M. G. (2008), The geology of Namibia, in The Geology of Namibia, Neoproterozoic to Lower Palaeozoic, edited by R. M. G. Miller, pp. 508, Ministry of Mines and Energy, Geol. Surv., Windhoek, Namibia.

Neff, P.D., Bertler, N.A.N. (2015) Trajectory modeling of modern dust transport to the Southern Ocean and Antarctica. Journal of Geophysical Research: Atmospheres 120, 9303-9322.

Noble, T.L., Piotrowski, A.M., Robinson, L.F., McManus, J.F., Hillenbrand, C.D., Bory, A.J.M., 2012. Greater supply of Patagonian-sourced detritus and transport by the ACC to the Atlantic 
sector of the Southern Ocean during the last glacial period. Earth Planet. Sci. Lett.317-318, 374-385. http://dx.doi.org/10.1016/j.epsl.2011.10.007.

Partridge, T.C., Demenocal, P.B., Lorentz, S.A., Paiker, M.J., Vogel, J.C. (1997) Orbital forcing of climate over South Africa: A 200,000-year rainfall record from the pretoria saltpan, Quaternary Science Reviews, 16, 1125-1133, doi.org/10.1016/S02773791(97)00005-X.

Prospero, J.M. (2002) Environmental characterization of global sources of atmospheric soil dust identified with the NIMBUS 7 Total Ozone Mapping Spectrometer (TOMS) absorbing aerosol product. Reviews of Geophysics 40, 1002.

Revel-rolland, M., Dedeckker, P., Delmonte, B., Hesse, P., Magee, J., Basiledoelsch, I., Grousset, F., Bosch, D. (2006) Eastern Australia: A possible source of dust in East Antarctica interglacial ice. Earth and Planetary Science Letters 249, 1-13.

Shannon, L.V., and Anderson, F.P. (1982) Applications of satellite ocean colour imagery in the study of the Benguela Current system. S Afr J Photogramm Remote Sens Cartogr 13(3):153-169

Shi, N., Dupont, L.M., Beug, H.-J., Schneider, R. (2000) Correlation between Vegetation in Southwestern Africa and Oceanic Upwelling in the Past 21,000 Years. Quaternary Research 54, 7280 .

Stuut, Jan-Berend W; Prins, Maarten A; Schneider, Ralph R; Weltje, Gert Jan; Jansen, J H Fred; Postma, George (2002): A 300-kyr record of aridity and wind strength in southwestern Africa: inferences from grain-size distributions of sediments on Walvis Ridge, SE Atlantic. Marine Geology, 180(1-4), 221-233, https://doi.org/10.1016/S0025-3227(01)00215-8.

Stuut, J-B.W. and Lamy, F. (2004). Climate variability at the southern boundaries of the Namib (southwestern Africa) and Atacama (northern Chile) coastal deserts during the last 120,000 yr. Quaternary Research, 62(3), 301-309, https://doi.org/10.1016/j.yqres.2004.08.001

Taylor, S.R., McLennan, S.M., (1985). The Continental Crust: Its Composition and Evolution. Blackwell, Oxford. 315 pp.

Tlhalerwa, K., Freiman, M.T., and Piketh S.J., (2005), Aerosol deposition off the Southern African west coast by Berg Winds, South African Geographical Journal, 87:2, 152161, DOI: $10.1080 / 03736245.2005 .9713838$.

Todd, M. and Washington, R., (1999). Circulation anomalies associated with tropicaltemperate troughs in southern Africa and the south west Indian Ocean. Climate dynamics, 15(12), pp.937-951.

Vallelonga, P. et al. (2010) Lead isotopic compositions in the EPICA Dome C ice core and Southern Hemisphere Potential Source Areas. Quaternary Science Reviews 29, 247-255.

Vanderstraeten, A., Mattielli, N.,Goulven G Laruelle, Bory, A., Gili, S., Gabrielli,P., Boxho, S., and Steeve Bonneville (2021). High-resolution statistical quantification of aeolian dust provenance in East Antarctica over the Last Glacial-Interglacial Transition, conference abstract presented at Goldschmidth 2021.

Vanderstraeten, A., Bonneville, S., Gili, S., Jong, J., Debouge, W., Claeys, P., Mattielli, N. (2020) First Multi-Isotopic (Pb-Nd-Sr-Zn-Cu-Fe) Characterisation of Dust Reference Materials (ATD and BCR-723): A Multi-Column Chromatographic Method Optimised to Trace Mineral and Anthropogenic Dust Sources. Geostandards and Geoanalytical Research ggr.12320.

Vanderstraeten, A., Gili, S., Mangold, A., Bonneville, S., Dietze, V., Walgraeve, C., Van Overmeiren, P., Berclaz, C., Goderis, S., \& Mattielli, N. (2019). Chasing dust in Dronning Maud Land, East Antarctica: A Trace Element perspective. Conference abstract presented at INQUA 2019.

Vermeesch, P., Fenton, C.R., Kober, F., Wiggs, G.F.S., Bristow, C.S. and Xu, S., 2010. Sand residence times of one million years in the Namib Sand Sea from cosmogenic nuclides. Nature Geoscience, 3(12), pp.862-865.

Vickery, K. and Eckardt, F (2013). Dust emission controls on the lower Kuiseb River valley, Central Namib. Aeolian Research. 10. 125-133. 10.1016/j.aeolia.2013.02.006.

Vickery, K.J., Eckardt, F.D., Bryant, R.G., 2013. A sub-basin scale dust plume source frequency inventory for southern Africa, 2005-2008. Geophys. Res. Lett. 40 (19),5274-5279.

Von Holdt, J.R., Eckardt, F.D., Wiggs, G.F.S. (2017) Landsat identifies aeolian dust emission dynamics at the landform scale. Remote Sensing of Environment 198, 229-243. 
Wang, J., Doussin, J. F., Perrier, S., Perraudin, E., Katrib, Y., Pangui, E., and PicquetVarrault, B.: Design of a new multi-phase experimental simulation chamber for atmospheric photosmog, aerosol and cloud chemistry research, Atmos. Meas. Tech., 4, 2465-2494, https://doi.org/10.5194/amt-4-2465-2011, 2011.

Wegner, A. et al. (2012) Change in dust variability in the Atlantic sector of Antarctica at the end of the last deglaciation. Climate of the Past 8, 135-147. 


\section{Supplementary Files}

This is a list of supplementary files associated with this preprint. Click to download.

- TABLESS1S2.xlsx

- CommEarthXEnvironmentSGSupplementaryMaterials.pdf 